\title{
EXPOSURE OF THE NASONOV GLAND BY HONEYBEES (APIS MELLIFERA) COLLEGTING WATER
}

\author{
by \\ J. B. FREE and INGRID H. WILLIAMS \\ (Rothamsted Experimental Station, Harpenden, Herts, England)
}

(Rec. I2-VI-I970)

Worker honeybees expose their Nasonov scent glands on flowers in exceptional circumstances (Frisch \& Rösch, I926; Free \& RaCey, I966), but readily do so when collecting sugar syrup. Adding an odour to a dish of sugar syrup diminishes the tendency of bees foraging on it to expose their Nasonov glands (FreE, I968; Wenner et al, 1969); thus, it seems that bees are particularly likely to add their own scent to a food source that lacks one and so facilitate its discovery by newcomers recruited by bee dances (FRISCH, 1946; 1967). Because odourless food sources are rare in nature, it is difficult to explain how this scenting behaviour could have evolved (FREE, I968). However, although bees prefer to collect water containing decaying vegetable and animal material, which often has a pronounced odour, to cleaner and odourless water (BUTLER, I940), the latter is frequently most easily obtainable. Hence we have now studied the scenting behaviour of bees collecting water.

\section{METHODS AND RESULTS}

On I6 June, I969, shallow unglazed earthenware dishes ( $18 \mathrm{~cm}$ diam.) were distributed at least $5 \mathrm{~m}$ apart in a garden containing numerous honeybee colonies. A continual supply of distilled water was maintained in I4 dishes and rain water mixed with decaying vegetation and mud (to be referred to subsequently as rain water) in 20 dishes. In the morning of 26 June, when many of the dishes were being visited by bees, each was observed for 5 minutes, and the bees that did and did not scent during this time were counted. These observations were repeated on the afternoon of 26 June, and on the morning and afternoon of 30 June. On each occasion the tendency to scent was much greater when collecting the distilled water than the rain water (Table I).

In the next experiment ( $\mathrm{r} 7 \mathrm{July}$ ) the possible effect of the taste of the water on Nasonov gland exposure was eliminated. Each earthenware dish was covered with wire gauze, on top of which was put a glass Petri dish containing distilled water. The 34 earthenware dishes used were allocated 
TABLE I

Comparison of the tendency of bees to scent on dishes containing distilled water and rain water

\author{
No. dishes \\ visited
}
Percentage of bees scented (total no. bees

Significance of in brackets) on dishes with : tendency to scent
26 June morning
afternoon

30 June morning afternoon

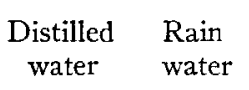

Rain

water

$\begin{array}{rrlll}7 & \text { 10 } & 56(48) & \text { I9 (48) } & \mathrm{P}<0.001 \\ 9 & \text { II } & 53(\text { I25) } & \text { 19 (I32) } & \mathrm{P}<0.001 \\ 5 & 8 & 67(\text { I2) } & 20(15) & \mathrm{P}<0.05 \\ \text { I0 } & \text { I3 } & 65(57) & \text { I3 }(62) & \mathrm{P}<0.001\end{array}$

alternately into two equal groups (A and B). Distilled water was put into all the earthenware dishes during the morning, but during the afternoon Group A dishes were filled with rain water. The behaviour of bees visiting each dish was observed for five minutes in the morning and afternoon as before. Scenting on Group A dishes was diminished in the afternoon (Table 2). In a series of similar experiments the earthenware dishes were kept empty during the morning observation, and a few drops of methyl benzoate or benzyl acetate, in a small glass dish, were put inside the earthenware

\section{TABLE 2}

Tendency of bees to scent in the presence or absence of an odour at the water site

Scent added o experimental roup in the iternoon Rain water o group A

Methyl enzoate o group B Benzyl icetate o group B Methyl senzoate o group A Benzyl icetate o group B
No. dishes visited

Experi- Control mental

I7 July morning afternoon I8 July morning afternoon 3I July morning afternoon 6 Aug. morning afternoon I4 Aug. morning afternoon

9
I0
I2
I2
8
I2
I0
I2
I0
12

9

9 I0

15

16

9

IO

Io

I5

Io

I2

I2

12

8

12

IO

I2

IO

12
Percentage of bees scented (total no. bees in brackets) on: Experimental Control group group of dishes of dishes

27 (164)

\begin{tabular}{|c|c|c|}
\hline $38(42)$ & $32(4 I)$ & nil \\
\hline Io $(92)$ & $35(89)$ & $\mathrm{P}<0.00 \mathrm{I}$ \\
\hline 33 (I 37$)$ & $23(8 I)$ & nil \\
\hline II ( 108$)$ & 22 (I26) & $P<0.05$ \\
\hline I4（28) & I4（29） & nil \\
\hline IO (93) & $21 \quad(165)$ & $P<0.05$ \\
\hline I9（77） & $22(68)$ & nil \\
\hline $5($ I65) & I7 (96) & $\mathrm{P}<0.01$ \\
\hline $24(67)$ & I9 (69) & nil \\
\hline $20(70)$ & 27 (I64) & nil \\
\hline
\end{tabular}

Significance of difference in tendency to scent

$32(4 \mathrm{I})$

nil

nil 
dishes of Group A or B in the afternoon. In all except the last experiment, adding an odour to the water source significantly diminished Nasonov gland exposure. This ef fect, together with the bees' natural preference for collecting water contaminated with organic material, which gives it a pronounced odour, probably explains why exposure of the Nasonov gland by water-gatherers has previously escaped detection.

Observations were also made on the behaviour of individual water-gatherers during several consecutive trips. On Io June bees visiting two dishes, $A$ and $B$,

\section{TABLE 3}

The scenting behaviour of individual bees during consecutive trips

\begin{tabular}{|c|c|c|c|c|c|c|c|c|c|}
\hline \multirow[b]{2}{*}{ Dish } & \multirow[b]{2}{*}{$\begin{array}{l}\text { Type of } \\
\text { water }\end{array}$} & \multirow[b]{2}{*}{ Date } & \multicolumn{2}{|c|}{ All bees } & \multicolumn{2}{|c|}{ All trips } & $\begin{array}{l}\text { Bees that } \\
\text { did not scen }\end{array}$ & \multicolumn{2}{|c|}{ Bees that sce } \\
\hline & & & $\begin{array}{c}\text { No. } \\
\text { foraged }\end{array}$ & $\begin{array}{c}\% \\
\text { scented }\end{array}$ & No. & $\begin{array}{l}\% \text { on which } \\
\text { bees scented }\end{array}$ & $\begin{array}{l}\text { Mean } \\
\text { no. } \\
\text { trips }\end{array}$ & $\begin{array}{c}\text { Mean no. } \\
\text { trips }\end{array}$ & $\begin{array}{l}\% \\
\text { on } \\
\text { sc }\end{array}$ \\
\hline A & Distilled & II June & 28 & $2 \mathrm{I}$ & 859 & I I & 26 & 48 & \\
\hline & Distilled & I2 June & 25 & 28 & 1027 & 3 & 40 & 44 & \\
\hline B & Distilled & I I June & 25 & 52 & 723 & I5 & 27 & 30 & \\
\hline C & Rain & 3 Sept. & 18 & II & 296 & 6 & 16 & 20 & \\
\hline & Distilled & 4 Sept. & 26 & 27 & 537 & I5 & 18 & 27 & \\
\hline D & Distilled & 3 Sept. & 30 & 77 & 1300 & 26 & 28 & 48 & \\
\hline & Rain & 4 Sept. & 21 & 33 & $32 \mathrm{I}$ & 9 & 14 & 32 & \\
\hline
\end{tabular}

$6 \mathrm{~m}$ apart, were given distinguishing paint marks. The dishes were emptied of water and refilled with distilled water on I I June when both were watched for three hours during the morning and three hours during the afternoon; dish A alone was watched for a further six hours on I2 June. Individual bees showed no consistency from one day to another in their tendency to scent, and only one of the six bees that scented at dish A on I I June was included among the seven that scented at dish A on I2 June (Table 3 ). It is not known why a greater percentage of bees scented at dish $B$ than at dish $A$.

In another experiment, the behaviour of marked bees visiting two dishes, C and D, was watched continuously for eight hours on 3 September and six hours on 4 September from when water was provided. Dish C contained rain water on 3 September and distilled water on 4 September, whereas dish D received the reverse treatment (Table 3). On 3 September the proportion of bees that scented, and the proportion of trips during which scenting occurred, was greater at the dish with distilled water than with rain water $(\mathrm{P}<\mathrm{O} .00 \mathrm{I}$ for each comparison) and on 4 September the proportion of trips during which scenting occurred was greater on the dish with distilled water $(\mathrm{P}<0.02)$. 
Bec; that scented made a mean of 16 trips ( 7 bees) before doing so when collecting rain water and I trips (34 bees) when collecting distilled water (difference not significant). Once they had begun to scent they continued to do so on only $26 \%$ and $50 \%$ respectively of their remaining trips. However, on average a bee foraging on rain water scented on $57 \%$ of the trips it made between the first and last trip on which it scented for the day, and a bee foraging on distilled water did so on $68 \%$ of such trips. The bees did not expose their Nasonov glands as readily or consistently when collecting water as when collecting concentrated sugar syrup (FREE, 1968) but this may merely reflect its relative attractiveness, and perhaps at times when water is in greater demand scenting is more pronounced.

Because a bee did not usually begin scenting for the day until it had made several foraging trips, it seemed unlikely that scenting was in response to difficulty in finding the water site. However, to test this possibility bees were observed foraging on dishes of distilled and rain water for five minutes as before, and then the dishes were moved $\mathrm{I} \mathrm{m}$ from their original sites, to confuse the bees temporarily, and again watched for five minutes. The percentage of bees that scented before and after displacement of dishes containing distilled water was $53 \%$ and $5 \mathrm{I} \%$ respectively and of dishes containing rain water was $29 \%$ and $29 \%$ respectively. Hence displacement of the dishes had no effect on Nasonov gland exposure.

\section{DISCUSSION AND CONCLUSIONS}

Under natural conditions Nasonov gland exposure by foraging bees is usually associated with water collection and not with nectar or pollen collection. Bees recruited to an attractive natural food source do not follow the dance directions very precisely (FRISCH, 1967); nor is it desirable that they should do so. A natural food crop is usually distributed over a considerable area, and, if the arrival points of the recruits are also widely distributed, a colony can exploit it more efficiently than if all its foragers concentrated on a small area. However, probably most naturally occurring water sites, other than early morning dew or rain, are more discrete than those of nectar or pollen and have less pronounced odours, and the exposure of the Nasonov glands by foragers at such sites helps recruits to find them sooner. It is not known whether bees expose their Nasonov glands when foraging on dew or rain drops, but it is doubtful whether this would commonly occur as they are likely to evaporate before the bees make sufficient trips to begin scenting. The exposure of Nasonov glands by bees foraging for nectar in glasshouses (FrISCH, I926; FrEE \& RACEY, 1966), or on dishes of odourless sugar syrup 
(FRISCH, I967; FREE, I968), is probably a response to an abundant supply of forage that is usually associated only with foraging for water. Arguments about the relative importance of dance communication and bee odour in the finding of dishes of sugar syrup by recruits (JoHnson, 1967; WENNER, rg67) are of doubtful validity when attempts are made to relate them to communication of floral sources of nectar.

\section{SUMMARY}

It has becn found that when worker honeybees have made several consecutive trips for water many of them expose their Nasonov glands at the source of supply, and especially when it lacks an odour of its own. It is suggested that the tendency of bees to expose their Nasonov glands when collecting sugar syrup or abnormally abundant supplies of nectar is an adaptation of the behaviour that naturally occurs when collecting water.

\section{REFERENCES}

Butrfr, C. G. (1940). The choice of drinking water by the honeybee. - J. exp. Biol. I7, p. 253 -26I.

FrEe, J. B. (Ig68). The conditions under which foraging honeybees expose their Nasonov glands. - J. apic. Res. 7, p. I39-I 45 .

— \& RACEY, P. A. (I966). The pollination of Freesia refracta in glasshouses. J. apic. Res. 5, p. $177^{-182}$.

Friscir, K. von (1946). Die Tänze der Bienen. - Österr. Zool, I, D. I-48.

- (I967). The dance language and orientation of bees. - London: Oxford University Press.

— \& Rösch, G. A. (1926). Neue Versuche über die Bedeutung von Duftorgan und Pollenduft für die Verständigung im Bienenvolk. - $Z$. vergl. Physiol. 4, P. I-2I.

Johnson, D. L. (I967). Honey Bees: Do they use the direction information contained in their dance manoeuver? - Science 155, D. $844-847$.

Wenner, A. M. (I967). Honey Bees: Do they use the distance information contained in their dance manoeuver? - Science I55. p. 847-849.

- Wells, P. H. \& Johnson, D. L. (Ig69). Honeybee recruitment to food sources; olfaction or language. - Science I64, p. 84-86.

\section{ZUSAMMENFASSUNG}

Wassersammelnde Honigbienen stïlpen nach mehreren einander folgenden Ausflügen beim Wasser oft ihr Duftorgan aus, besonders wenn dort ein Eigengerucht fehlt. Verfasser neigt dazu, das gleiche Ausstülpen des Duftorgans am Zuckerwasserschälchen oder ungewöhnlich reichen natürlichen Nektarspendern auf das gleiche Verhalten der Wassersammlerinnen zurückzuführen. 